\title{
Metropolitan Emblems or Symbols in Globalization? Both for the Future of Metropolises and Their Citizens
}

\author{
Christian Sallenave \\ Research Laboratory GRECCAU, Bordeaux Higher School of Architecture and Landscape Design, Talence 33400, France
}

\begin{abstract}
This research concerns on "metropolis and metropolisation": what is new with the symbols of city local life and the emblems of global competition? From New York, Rome, Barcelone, Paris and Bordeaux, the same question demands specific answers: can we live and appreciate urban and metropolitan symbols and emblems together or on their own? That is the question for towns and the future of their citizens. Confrontation of urban sites and observed places with the plural points of view of their establishment, their designers and urban skills, and their inhabitants and citizens. The combination of these several points of view always make a richer discovery than their disciplinary partition and monopoly.
\end{abstract}

Key words: Town and metropolis, improvisation in globalization, enhance flows' management, emblems and symbols, multiple political levels of the establishment and civil service, centipede of social networks.

\section{Introduction}

The goal of this article is to study the relationship between towns and metropolises through the actual globalization, between symbols of city life and emblems of global competition. This is not only question of establishment's power and skills of professions, but also an urban and metropolis question between establishment, civil service and social networks, their urban improvisations and the metropolis flows' management.

The author's previous researches concerned "the interdisciplinary approaches facing nowadays environmental challenges". Coming back from New York, London, Rome, Barcelone, Paris to Bordeaux, the author would show that the actual metropolitan growth is not only question of urban history and geography, but also a question of new metropolitan space-time, and relationship between networks' powers and ways of life, of elites and citizen.

Corresponding author: Christian Sallenave, Ph.D. sociologist, research fields: environment, architectural and urban design, identities and ways of life.

\section{Metropolitan Emblems and Symbols}

\subsection{Same Plural Metropolitan Problems All over the} World?

In France and Italy, the Law of the January 1st, 2016, has established in the same way and in the same time, the principal towns as new metropolises (15 in France, 10 in Italy). Apart from the fact of the state government, Rome, "the eternal city", Paris, the "capital of arts", or London, the financial City, are confronted by the same competition between metropolises than New York, Bordeaux or Barcelona. The same economic problems exist in this critical time, the same artistic or architectural heritages, the same attraction of their neighborhood, the same concentration of touristic flows, and globalized events (pilgrims, sport competitions, show business festivals and fashion shows). The economic and establishment's points of view demand long-term investments as logic answers.

We have also studied the answers of the inhabitants, in order to see how these different evolutions can be balanced, and the singular and specific answers of each metropolis for the future of towns and their 
citizens.

\subsection{The Singular Answer of Each Situation}

People seem "to be often overtaken by events". It is the condition of success for the events and business speech which can claim to become a new emblem of the town.

But, it is a condition of real urban-success in future, people must also appropriate the event, or a new place, as if it was "his own" or "his place of birth". How many private "selfies" appropriate the public spaces, how many tweets or sms replace history by their own memories.

In Rome (Fig. 1), cupolas and coliseum symbols are well known to all the world, the antiquity of an empire's metropolis, etymology of town's mother, and for everybody, "panem and circences", still nowadays, the reality of political and metropolitan life.

In Paris (Fig. 2), the "Arc de Triomphe" and the "Champs Elysées" (in French language for everybody) gather people and everybody around "the most beautiful city of the world" that everybody must visit once during his life, as Venise for the lovers.

The difference between these two situations is that emblems distinguish the winners among the "world competition", and symbol gathers together people around historic institutions and shared memories, as indicated by the Greek etymology of symbol.

\subsection{Emblems and Symbols Together: Terms of Specific Metropolitan Success}

It is very interesting to remark the difference between an event which becomes an emblem or a symbol and an event which gathers together emblem and symbol for people, inhabitants, tourists, and for the building, place and town concerned.

We can learn two specific lessons from European capitals - Rome, London and Paris — through different events of the same metropolitan globalization.

In Rome, with his new "Parco della Musica", the famous architect Renzo Piano has designed a "plural music center" from an urban highway area. And a bar, a restaurant, a library, and walk and conviviality area for families and visitors who keep and share the secret of their cities' history. Century Cupolas and umbrella pines (Fig. 1), villa and piazza, thus, everybody enjoys the finer things in life of the metropolises in globalization. Isn't it the better answer for a metropolis confronted as everyone with the global problem of migrants and homeless people? What the "Shard", nick name of the highest and luxurious skyscraper in London, also designed by the same famous

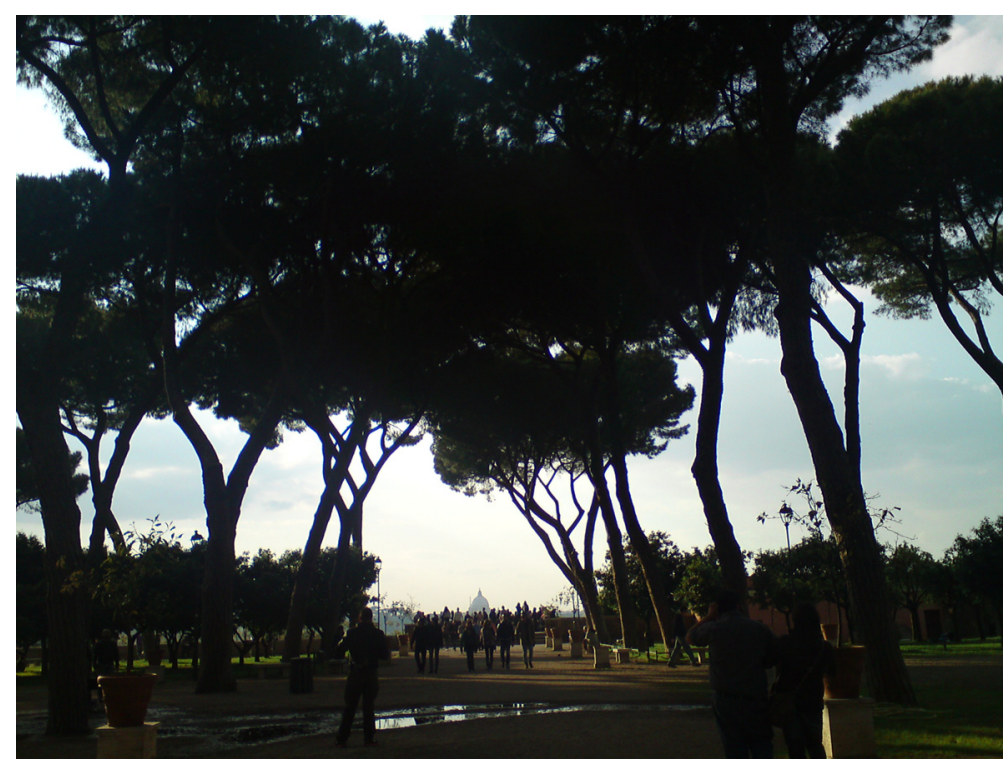

Fig. 1 Cupolas, "villas", umbrella pines in Rome.

Source: photo by Sulivan, R. 
architect Renzo Piano, will never equal, in the biggest metropolis and the first financial city of Europe. Indeed, the Shard is raised and reduced to an emblem of a financial wealth's skyscraper.

Here is the second example in Rome. During a concert of the Symphonic Orchestra Santa Cecilia, his musicians acted jointly with two marvels, the pianist Richard Hyung Joo and the violinist Aleksey Igudesman [1]. Not only these two soloists, but also all the musicians of the Philharmonic Orchestra, have improvised together on the most classic pieces of music combined with pieces of popular music, like James Bond and film music of Ennio Morricone. Gathered together with public in a standing ovation, the thanks were translated in merci, graziemille and Danke Schön, by everybody, public and musicians, each one in his pleasure, as symbols of the "most glad city life" and in the same time, emblems of the best quality of music and show-biz.

In the opposite direction, in Paris, at the moment of inauguration of the new auditorium (The Philharmonie), designed by the famous architect Jean Nouvel, the major project was not strictly finished, and the architect was absent for the first concert gala. The problem was not the quality of music or building, but, one more time, the never-ending question of who decides of "the final cut". The architect artist or the building's owner? The linguistic difference between English and French gives us a good lesson of sociology of art. The prime contractor is called "maître d'oeuvre" in French, the "master of fine art". And the project owner is called "maître d'ouvrage" in French, another one but always a "master". Therefore, it seems more important to claim to sovereignty than to exercise and practice his skills in interdisciplinary approaches [2]. In that case, the flows' management has priority over the quality of art and of life, and becomes one of the most important stakes and emblems of the metropolises in the globalization.

The consequence is that the debate on flows' management is not about a simplistic opposition between "slowness" and "speed", between past and modernity. The real question concerns the continuous flow acceleration, resulting in the compression of individuals and information in "tubes" and "networks", compression of the areas' history and individual memories in continuous events.

In these generalized compressions, the most intense noise prevails, the most repeated image is stupefying.

Regardless whether it concerns the global competition among major cities for their attractiveness or the virtual race through Internet to become the most visited site on the screen, the logic of "the winner takes all the market" prevails and imposes its type of competition: that of the blockbuster [3].

The skylines of major cities, and their skyscrapers, in Chicago and New York, then in Singapore, Kuala Lumpur, Shanghai or Dubai, London and Paris, are generally for business districts, and constructed by their architects and their project owners, for their trendy technological prowess and their precarious momentary emblems of "tallest tower in the world". No one, among these straight buildings, has the same symbolic significance as Freedom Tower of the One World Trade Center, in New York (Fig. 3), or the Eiffel Tower in Paris, since the Universal Exhibition, in1889 (Fig. 2).

In this metropolitan competition, indeed, the more these emblems differentiate from each other, the more we are undifferentiated in the race of singularity.

We can neither understand and resolve these problems of globalization competition, with spatial disciplines like urban planning, architecture or geography, nor resolve the problems of flows' acceleration by history of masterpieces. History and geography, and their "panoptique" [4] disciplines (urban planning and urban design) think that the future of a metropolis is, like their projects and design, unilaterally and ineluctably determined.

My question is not a question of towns and of big metropolises, but of the "metropolisation", the process of emblems and symbols in the same time, cities and 


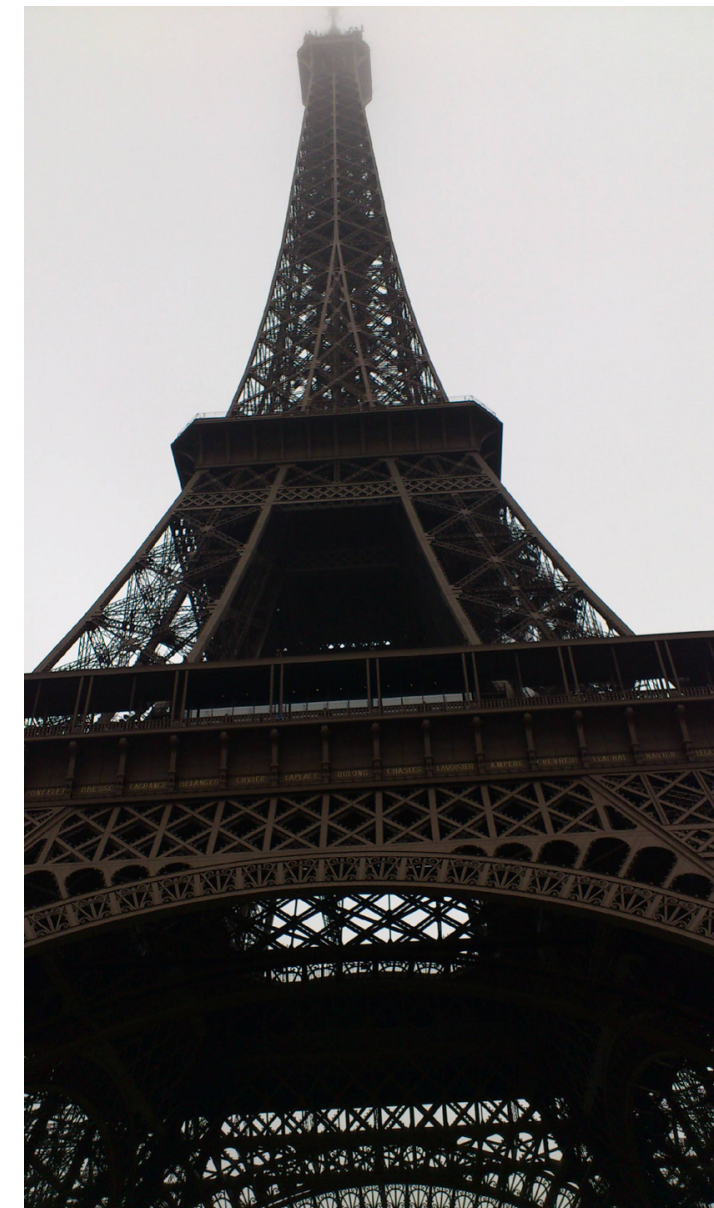

Fig. 2 The Eiffel Tower emblem and symbol of Paris since 1889.

Source: photo by Sulivan, R.

metropolis built and destroyed, designed and lived, hated and loved, real and virtual, present and past, present and future.

With the flows' acceleration, the time is dilated and the space contracted, instantaneous timing and spatial ubiquity, on the Internet and worldwide events. This new metropolitan space time is a continuous history and memory of tensions and articulations. It requires the analysis of multidisciplinary richness to enhance the flows by our history and memories rather than checking in vain the flows' acceleration.

\section{Space Time of Metropolises and Their Towns}

The second skate of centrifugal and centripetal forces, between downtowns and suburbs or outskirts of cities, between downtowns, edge cities, edgeless cities and urban sprawl [5] do not determine an unilateral process of urban gentrification and relegation, as a project or a movie, those the scientist would know the future as if it was a happy or unhappy end.

It is studied here as a double movement, sometimes "double bind", always several and continual interferences of inferences [6] and concentrations of powers and negotiations, satellisations and backward and forward movements, between urban plannings and improvisations, establishment, public services and social networks, as we will see, now, in several metropolises and their towns.

\subsection{Two Big Metropolises, New York and Paris, Show} Similar Skates in Their Process of "Metropolisation"

New York, between the 1930s and 1970s, with Robert Moses, the town planner who modernized or compromised, according to the different points of view, her future, has been known for an exceptional multiplication of urban freeways. But New York has also, with her citizens and establishment, saved her Central Park, surrounded by skyscrapers, offering us the landscape setting as a true "urban gift".

The famous mythical energy, everyone is talking about, that emerges from this "global capital", does not create an optical illusion, able to make its stories and sagas our example, and its networks and flows of compression our perceptions and sensations.

The daily display panels of Times Square, their flashing screens that make us dizzy, and the skyline of Manhattan, intending to make us dream, do not confuse their image with our sensations.

These virtual worlds and these metropolitan "artefacts" are not all from New York. The plural memories of so many immigrations, visitors and inhabitants, also create a unique history of this city, neither autarkic nor endogamous. As Tolstoï said, if you want to think universally, speak of your village. As scientist think and speak nowadays "glocal". 


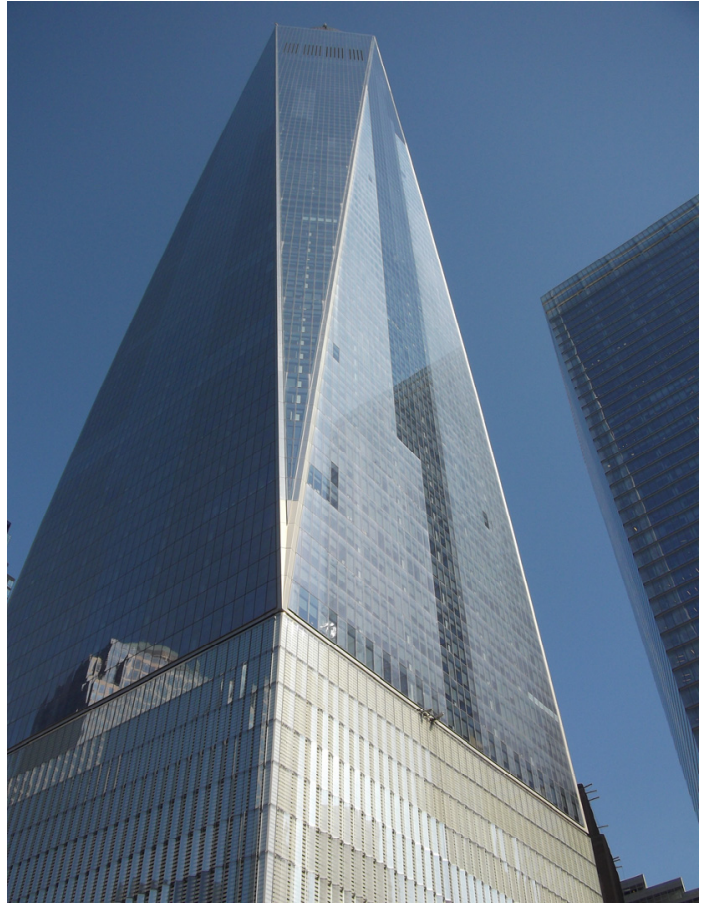

Fig. 3 The Freedom Tower, an emblem and a symbol of New York City.

Source: photo by Sulivan, R.

Paris (more than 2 million inhabitants intramural and almost 12 millions in the "Ile de France" area, (two times the density of New York) faces a similar challenge with the future metropolitan project of the "Great Paris", le "Grand Paris".

Will it turn into an endless urban and metropolitan flow of new subways, tramways, overhead railway, and new skyscrapers always faster and higher? Or into new mineral and vegetable landscapes, which combine the "blue" and the "green" corridors of the Seine River and natural and urban biodiversity [7]? And which will offer for Paris 24, candidature to Olympic Games of 2024, not only a dream, not only a month of planetary event, but also a challenge of sustainable metropolitan development, through new practices of sports in the city during the 21 st century.

\subsection{Bordeaux, in France, a Study of New "Metropolisation"}

Bordeaux Metropolis, with Bordeaux and the 27 other towns of her metropolitan area, actually 750,000 inhabitants, will get one million inhabitants by 2030 .
Her new tramway, since 2002, which connects downtown of Bordeaux and the towns of her periphery, but not yet directly connect these suburb towns themselves, has two consequences.

Yesterday, the young inhabitants of suburbs said that "they went to Bordeaux". Today, they say that "they go downtown". Thus, they reach easily the historical center of Bordeaux with tramway, and they can spend their Sunday afternoons at the Water Mirror, in front of the majestic Place and Palais de la Bourse (1749) [8], an architectural heritage that they did not mix with before.

The first "metropolisation" question is the following one: will Bordeaux become an touristic sanctuary, with the gentrified central districts, and the towns outskirts become cultural and conviviality deserts?

The second metropolitan question is: what is new with this urban symbol composition, the figure of Miroir d'eau, Water Mirror? Like in Castle of Versailles in the 18th century? Or like a metropolis of 21 st century?

In the beginning of the 20th century, the Bordeaux architects Pierre Ferret and Cyprien Alfred-Duprat, were asked to develop "la place des Quinconces" in Bordeaux on the river bank. The project was to create a garden "à la française" (like in Chateau de Versailles) with lawns, charms and Water Mirror, and to build at the border of the quays two identical palaces, one reserved for festivities and the other for fine arts. The World War I (1914 1918) postponed the project indefinitely [9].

Nowadays, the Water Mirror [10] (Fig. 4) is, at the same time, an emblem of City of Bordeaux and a symbol of Bordeaux Metropolis. It assembles together an increasingly amount of tourists and inhabitants of Bordeaux, exceptional events and daily pleasures, around its Garonne banks, "reconquered" by the entire population, in front of the most beautiful and prestigious facades of the 18th century in Europe, of the "Place de la Bourse". 


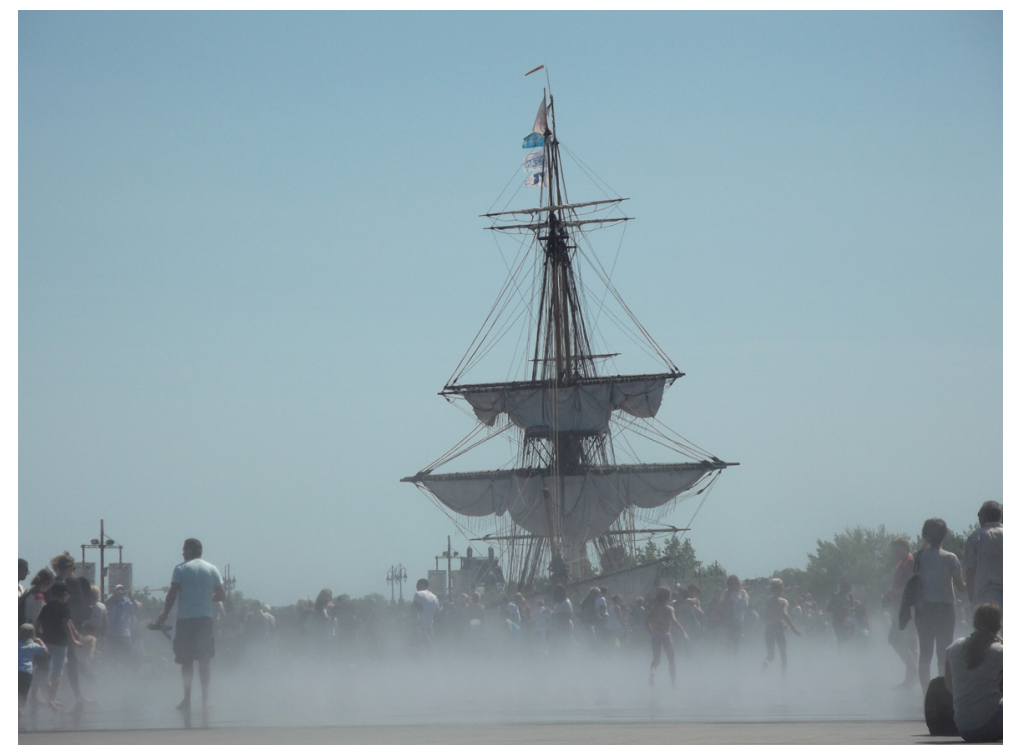

Fig. 4 The Water Mirror in Bordeaux and the Hermione (frigate), before leaving for New York. Source: photo by Sulivan, R.

Americans, Japanese, Chinese, Australians and many other nationalities, disembark there from their luxury cruising ships, with their Nikons on their belly, and their mobile phones hanging on their chest, before starting their visit of the castles of the prestigious Bordeaux wines and vineyards.

And the Place des Quinconces and the Garonne banks also become a munificent fan zone during the football World Cups and Olympic Games.

The second condition of metropolitan sustainable development is that the other towns of Bordeaux's area are not specialized and relegated as metropolitan "satellites".

Merignac, 70,000 inhabitants, should not be reduced to her airport of Bordeaux-Merignac and her aerospace industry and flows of cars during work times; Pessac, 46,000 inhabitants, should not be reduced to his prestigious castles of wine (Pape Clément, Haut Brion) and her History Film Festival and her University of Letters and Law; Cenon, 24,000 inhabitants, on the right river bank, should not be reduced to her suburb blocks and new Rocher de Palmer for world music; and Talence, 43,000 inhabitants, should not be reduced neither to an administrative subdivision of Bordeaux Metropole, nor to her Decastar, Decathlon championship, and her scientific university, in a campus left as an urban orphelan, whereas it would have become also a central park in the future of the new Bordeaux metropolis.

\subsection{The Question of Metropolisation Is Not Only a} Question of a New "Metropolitan Space Time"

It is also a question of multidisciplinary works together and negotiations between elites and citizen, through judgmental doped [11] and well known gulfs as impassable.

The political and administrative powers are so many in the same metropolitan territory-city, edge cities, metropolises, department (Provincia in Italy) region, state, European Union-that working progress is the diary condition of work for each one. It is when they improvise together that each one is considered a visionary.

It is the same logic for the individuals in the social networks. When everyone writes his e-mail or tweet, he is persuaded that his truth must become the truth all over the world.

To resolve these problems of metropolitan complexity, and to succeed in this urban relay race, the future must be improvised not only in opposition 
of networks, between dream teams, "millefeuille", multiple political and administrative levels of the establishment and civil service and "centipede" of social networks, but also through tensions and articulations between history and memories, skills and ways of life, working in progress and in concert, and to balance and conciliate the future of an "European metropolis" and of a "provincial town, and region's prosperous capital".

\section{Conclusions}

Barcelone is a good example of the metropolitan stakes. This metropolis was never reduced to her unfinished cathedral of Antonio Gaudi, his Sagrada familia, emblem of this European metropolis and symbol of masterpiece of modern style.

Las Ramblas, the famous avenue of Barcelone, and the gothic district, Barrio Gotico, others emblems and symbols in the same time, combine touristic flows and business with their citizens' memories of the "Catalonia capital".

Since Olympic Games of 1992, Barcelone became an emblematic "global metropolis" because of her touristic flows (12 millions of tourists, and 3 millions of inhabitants) and upsurge of the price of the apartments. In the same time, Barcelone remains the Catalonia symbol for everybody all over the world. The Football Club of Barcelone, "Barça", and the famous Nou Camp, show how she combines the sponsoring of sport business, with Qatar Airways, after UNICEF (United Nations International Children's Emergency Fund), her memory of the most beautiful football, played by her dream team, and the fan club of 98,000 "socios", subscribers among a stadium of 100,000 seats.

It is a good example for the stakes of metropolisation of our cities, towns, and metropolises.

We can face the future of new generations by reconciling and combining anytime and anywhere, the memories and the history of their society, the symbols that unite them as partners and the emblems that distinguish and oppose all of them as rivals. It is a question of daily translation.

In Montreal, at a conference of the ISUF (International Seminar of Urban Form) 2011, my accent and my English improvisation made some smile which made me think of John Dewey [12], who wrote a long time ago, in 1915: "A work of art is recreated at each of interpretations".

What is true for a Beethoven's Symphony, a standard of Louis Armstrong, Duke Ellington or Charlie Parker, or a Rembrandt's Ronde de Nuit, is also true for the Coliseum in Rome, the Guggenheim Museum in New York (Franck Lloyd Wright architect), the Louvre Pyramid (architect I. M. Pei) or the Water Mirror in Bordeaux (landscape designer M. Corajoud, Fig. 4). It is truer when it concerns a city and metropolis which are always experienced, improvised by chiefs of urban orchestra, jazz band maestros and soloists, and every citizen, in metropolitan plural and singular, at the same time.

These collaborations and works are universal where they have the power to inspire continually unique experiences. And this is why they always result in a specific history and memory.

As Daniel J. Boorstin [13] wrote: There is nothing better than a translation. For the rich exchanges and flows, especially, that is what we observed in our metropolitan trip [14], when it is experienced as a public and a group of jazz musicians, adapting to the rhythm of each language interacting together.

Nothing is better in the globalization, for our towns and metropolises and their citizens and visitors, than a balance of emblems and symbols, through dialog of interferences and go back and forth between skills and memories, elites and citizen.

\section{References}

[1] Joo, I. 2015. A Big Nightmare Music. Auditorium Parco della Musica, Sala Santa Cecilia, 09/07/2015.

[2] Sallenave, C. 2012. "The Plural in Singular, City and Discipliary Batallions? Interdisciplinary Approaches Facing Nowadays Environmental Challenges.” Journal of 
Civil Engineering and Architecture 6 (12): 1635-41.

[3] Elberse, A. 2013. Blockbusters—Hit Making, Risk Taking, and the Big Business of Entertainment. New York: Henry Holt.

[4] Bentham, J. 1791. "Panoptique." In Survey and Punish, edited by Foucault, M. Paris: Gallimard

[5] Ghorra-Gobin, C. 2003. Cities and Urban Society in United States. Paris: Colin. (in French)

[6] Abbott, A. 1988. The System of Professions: An Essay on the Division of Expert Labor. Chicago: The University of Chicago Press.

[7] Cottenceau, I. 2013. If Paris Became Green? Arte Film, Naturapolis. (in French)

[8] Sallenave, C., and Boisseau, J. P. 2012. Arts and Culture in Globalization, Once upon a Time ... Bordeaux, Paris, l'Aquitaine. Paris: Bastingage.(in French).
[9] Sallenave, C., Caumes, P., and Miteneva, N. 2011. The Ferret, One Century of Architectures, Questions of Ways of Life and Dwelling. Paris: Editions Bastingage.

[10] Corajoud, M. A. 2008. Bordeaux Paysages de Lumières, in Bordeaux-Unesco, The Stakes of Unesco Heritage. Paris: Editions Bastingage. (in French)

[11] Garfinkel, H. 1984. Studies in Ethnomethodology. Cambridge: Cambridge Polity Press.

[12] Dewey, J. 1915. Art as Experience. Illinois: Southern Illinois University Press.

[13] Boorstin, D. 1983. The Discoverers, A history of Man's Search to Know His World and Himself. New York: Randon House.

[14] Sallenave, C. 2016. Metropolitan Trip, Bordeaux, Rome, Florence, Paris, Works in Concert? Paris: Bastingage. (in French). 